\title{
PENGARUH PELATIHAN DAN PENGALAMAN KERJA TERHADAP KINERJA KARYAWAN PT. YI SHEN INDUSTRIAL
}

\author{
Ahmad Gunawan \\ Universitas Pelita Bangsa \\ Email korespondensi: ahmadgunawan@pelitabangsa.ac.id
}

\begin{abstract}
This research aims to determine the influence of training and work experience on the employee performance of PT. Yi Shen Industrial. This study used a sample of 76 respondents, data collection using questionnaire method and tested with computerized data analysis method SPSS. The research uses validity test data analysis, reusability test, classical assumption test, double linear regression analysis and hypothesis test i.e. $T$ test to test and compare $T$ value with $T$ table or by looking at the value of significance. While F test to test when independent variables are simultaneously have significant or insignificant influence with the dependent variables. $T$ Test for the training $\left(X_{1}\right)$ obtained $t$ value $=25,913$ with a significant value of $(25,913>1,993)$ and for work experience variables $\left(X_{2}\right)$ acquired $T$ value $=3,622$ with a significant value of $(3,622>1,993)$. Therefore, $\mathrm{Ho}$ is rejected so that $\mathrm{Ha}$ is significant. Training and work experience are individually influence the employee's performance is accepted in this research. $F$ Test hypothesis testing simultaneously gained $f$ value $=484,220$ with a significant value of $(484,220>3.12)$. Therefore, Ho was rejected. So it can be concluded that the training variables $\left(X_{1}\right)$ and work experience $\left(X_{2}\right)$ simultaneously significantly influence the employee performance variable $(Y)$.
\end{abstract}

Keywords: Training, Work Experience, Performance

\section{A. PENDAHULUAN}

Keberhasilan suatu organiasi atau lembaga dalam mencapai tujuannya tidak terlepas kaitannya dari sumber daya manusia. Hal ini dikarenakan sumber daya manusia memegang suatu peran yang penting dalam mencapai tujuan perusahaan. Walaupun peran dan fungsi dari tenaga kerja telah banyak digantikan dengan teknologi yang semakin canggih, tetapi pada kenyataannya sampai saat ini tenaga kerja masih menjadi faktor yang penting dalam menentukan jalannya proses produksi. Oleh karena itu, perusahaan menghendaki agar setiap tenaga kerja dapat bekerja secara efektif dan efisien. Jadi perusahaan perlu mengelola dan mengembangkan SDM dengan baik (Leatemia, 2018). Berhasil atau gagalnya pelaksanaan fungsi - fungsi sumber daya manusia dalam perusahaan sangat bergantung pada sejauh mana kualitas sumber daya manusianya. Kondisi tersebut menunjukkan betapa penting dan strategisnya pengembangan dan peningkatan kualitas sumber daya manusia dalam perubahan yang terus berkembang. Sumber daya manusia yang berkualitas akan sangat menentukan maju mundurnya perusahaan di masa mendatang. 
Karyawan merupakan kekayaan (aset) utama perusahaan, sehingga harus dipelihara dengan baik. Faktor yang menjadi perhatian dalam manjemen sumber daya manusia adalah manusianya itu sendiri. Saat ini sangat disadari bahwa sumber daya manusia merupakan masalah perusahaan yang sangat penting, karena dengan sumber daya manusia menyebabkan sumber daya yang lain dalam perusahaan dapat berfungsi. Sumber daya manusia dapat menciptakan efisiensi dan efektivitas. Melalui sumber daya manusia mengharuskan manajer atau pimpinan dapat menemukan cara terbaik dalam mendayagunakan orang - orang yang ada dalam lingkungan perusahaannya agar tujuan - tujuan dapat tercapai.

Tercapainya tujuan perusahaan salah satunya sangat bergantung pada baik buruknya kinerja karyawan. Kinerja merupakan tingkat keberhasilan seseorang atau kelompok orang dalam melaksanakan tugas dan tanggung jawabnya serta kemampuan untuk mencapai tujuan dan standar yang ditetapkan. Kinerja diartikan sebagai ungkapan kemajuan yang didasari oleh pengetahuan, sikap dan motivasi dalam menghasilkan suatu pekerjaan. Untuk itu perusahaan harus mampu memperhatikan karyawan, mengarahkan, serta memotivasi untuk meningkatkan kinerja karyawan. Karyawan yang memiliki kinerja yang baik akan dapat menjalankan pekerjaan sesuai dengan tugas yang dibebankan padanya, mengerti kaitan pekerjaanya dengan tugas orang lain, mengerti target perusahaan, serta mampu mengatasi kesulitan yang dihadapi dalam menjalankan tugasnya. (Yunita \& Zuhro, 2018)

PT. Yi Shen Industrial merupakan salah satu perusahaan manufacturing di bidang otomotif yang berada di kawasan industri Cikarang, dalam perusahaan ini yang menjadi hal penting adalah karyawan lapangan yaitu karyawan yang langsung terjun pada pekerjaan seperti operator produksi. Seluruh karyawan lapangan di perusahaan berjumlah 76 orang karyawan. Ada beberapa masalah yang terkait dengan kinerja karyawan yang dihadapi oleh perusahaan diantaranya banyak karyawan yang tidak hadir tanpa ijin sebelumnya dan masih adanya karyawan yang sering datang terlambat. Selain itu pengelolaan sumber daya manusia khususnya karyawan lapangan banyak melakukan kesalahan yang berakibat terjadinya ketidaksesuaian produk yang dihasilkan menjadi Not God (NG) sehingga menimbulkan claim customer. Data hasil produksi karyawan pada bulan Desember 2018 sampai dengan April 2019 dapat dilihat pada Tabel 1.

Berdasarkan hasil pengamatan data yang diperoleh dari staff admin produksi PT. Yi Shen Industrial pada tabel 1, setiap bulannya semakin banyak hasil produksi yang not good (NG). Hal ini dapat dikatakan sebagai menurunnya kinerja karyawan berdasarkan data hasil produksi. Masalah ini disebabkan kurangnya pengalaman dan pemahaman karyawan mengoperasikan 
mesin produksi atau cara proses yang benar menurut prosedur kerja. Hal ini mengindikasikan bahwa pelatihan yang diberikan perusahaan masih sepenuhnya belum berhasil. Di sisi lain ada beberapa karyawan senior dalam hal ini adalah mereka yang memiliki pengalaman kerja yang cukup dan sudah bekerja lebih dari 3 tahun, sering kurang mau mengikuti pelatihan. Mereka beranggapan merasa sudah mampu menyelesaikan pekerjaan yang menjadi tanggung jawabnya karena sudah dianggap menjadi kebiasaan. Hal ini tentunya akan dapat mengurangi kinerja perusahaan secara umum.

Tabel 1. Hasil Produksi Perusahaan

\begin{tabular}{|l|l|c|c|c|}
\hline No & \multicolumn{1}{|c|}{ Bulan } & $\begin{array}{c}\text { Rencana } \\
\text { Produksi }\end{array}$ & $\begin{array}{c}\text { Hasil Produksi } \\
\text { (Good Quality) }\end{array}$ & $\begin{array}{c}\text { Hasil produk NG } \\
\text { (Not Good) }\end{array}$ \\
\hline 1 & Desember & $18.200 / \mathrm{Pcs}$ & $17.850 / \mathrm{Pcs}$ & $350 / \mathrm{Pcs}$ \\
\hline 2 & Januari & $22.720 / \mathrm{Pcs}$ & $22.320 / \mathrm{Pcs}$ & $400 / \mathrm{Pcs}$ \\
\hline 3 & Februari & $19.500 / \mathrm{Pcs}$ & $18.950 / \mathrm{Pcs}$ & $550 / \mathrm{Pcs}$ \\
\hline 4 & Maret & $20.700 / \mathrm{Pcs}$ & $19.380 / \mathrm{Pcs}$ & $1320 / \mathrm{Pcs}$ \\
\hline 5 & April & $15.400 / \mathrm{Pcs}$ & $13.770 / \mathrm{Pcs}$ & $1.630 / \mathrm{Pcs}$ \\
\hline
\end{tabular}

Sumber: Data produksi PT. Yi Shen Industrial (2019)

Pada dasarnya pelatihan merupakan proses yang berlanjut dan bukan proses sesaat saja. Terutama disaat perkembangan teknologi dan pengetahuan yang berkembang pesat seperti saat ini, peran pelatihan sangat besar peranannya untuk membekali pegawai agar lebih kreatif dalam mencapai tujuan perusahaan secara efektif dan efisien. Sementara secara umum tujuan pelaksanaan pelatihan adalah memperbaiki efektifitas dan efisiensi kerja karyawan, meningkatkan keterampilan di luar sistem pendidikan yang berlaku dalam waktu yang relatif singkat dengan metode yang lebih mengutamakan praktik daripada teori. Hal ini dilakukan agar karyawan dapat melaksanakan dan mencapai sasaran program-program kerja yang telah ditetapkan perusahan. Al-Karim (2019) berpendapat bahwa pelatihan ini sangat penting diadakan dalam perusahaan karena dirancang untuk karyawan dalam membenahi kelemahan kinerja mereka, memperoleh sikap, kemampuan, keahlian pengetahuan, pengalaman dan perilaku yang spesifik yang berhubungan dengan pekerjaan. Dengan adanya pengetahuan yang dimiliki tersebut secara langsung karyawan dapat menunaikan aktivitas atau pekerjaan tertentu, yang nantinya akan berdampak pada kinerja yang dicapai oleh karyawan. Berdasarkan penelitian yang dilakukan oleh Anggita \& Tjahyanti (2017) menghasilkan kesimpulan bahwa pelatihan berpengaruh terhadap kinerja pegawai negeri sipil. Hal ini berarti pelatihan menjadi faktor yang mempengauhi kinerja karyawan.

Selain pelatihan faktor lain yang mempengaruhi kinerja karyawan adalah pengalaman kerja. Pengalaman kerja biasanya didapatkan pada karyawan yang memiliki jam kerja yang 
lebih banyak. Semakin banyak pengalaman kerja yang didapatkan oleh karyawan maka akan semakin berkualitas karyawan tersebut. Pengalaman kerja karyawan menunjukan tingkat pengetahuan dan penguasaan keterampilan (softskill). Keterampilan seorang karyawan yang didapat dari pelatihan dan pengalaman kerja karyawan tersebut. Pengalaman kerja didapatkan pada karyawan yang telah memiliki jam kerja lebih banyak yang diharapkan akan mempunyai berbagai macam pengalaman dalam memecahkan bermacam-macam persoalan. Berbekal pengalaman tersebut diharapkan tiap-tiap karyawan mempunyai kualitas sumber daya manusia yang tinggi dalam meningkatkan kinerja pada perusahaan (Rachmawati, 2017).

Untuk meningkatkan kinerja karyawan dapat terus ditingkatkan melalui pelatihan kerja. Dengan adanya pelatihan kerja setiap karyawan dapat memperbaiki setiap kesalahan-kesalahan yang mungkin pernah dilakukan, agar dapat lebih mengembangkan kemampuan, talenta, serta ketrampilan yang ada sehingga dapat berpengaruh terhadap sebuah kinerja atau prestasi kerja yang baik. Pengalaman kerjapun sangat berpengaruh dalam menyelesaikan setiap tugas yang telah dibebankan. Karyawan yang telah memiliki pengalaman kerja yang baik sebelumnya, akan mampu segera beradaptasi baik dengan pekerjaan yang ada maupun dengan lingkungan kerja yang ada di sekitar. Dalam dunia kerjapun suatu lingkungan kerja yang aman dan nyaman sangat dibutuhkan bagi semua karyawan dalam menyelesaikan setiap tugas dan dapat bekerja secara optimal.

Berdasarkan uraian tersebut di atas mengenai pelatihan, pengalaman keja serta kinerja karyawan, dan fakta yang ada dilapangan sehingga peneliti tertarik untuk melakukan penelitian berjudul "Pengaruh Pelatihan Dan Pengalaman Kerja Terhadap Kinerja Karyawan PT. Yi Shen Industrial"

\section{B. TELAAH PUSTAKA}

Menurut Simanjuntak dalam Yunita \& Zuhro, (2018) kinerja adalah tingkat pencapaian hasil atas pelaksanaan tugas tertentu. Kinerja perusahaan adalah tingkat pencapaian hasil dalam rangka mewujudkan tujuan perusahaan. Menurut Sedarmayanti dalam Octavianus (2018) Kinerja merupakan hasil kerja seorang pegawai, sebuah proses manajemen atau suatu organisasi secara keseluruhan, dimana hasil kerja tersebut harus dapat ditunjukkan buktinya secara konkrit dan dapat diukur (dibandingkan dengan standar yang telah ditentukan). Menurut Hasibuan dalam Rachmawati, (2017) kinerja adalah suatu hasil yang dicapai seseorang dalam melaksanakan tugas-tugasnya yang dibebankan kepadanya yang didasarkan atas kecakapan, pengalaman, dan kesungguhan serta waktu. Menurut Umam dalam Kapahang, Kojo, \& Uhing, 
(2017) kinerja adalah hasil kerja yang dicapai oleh individu sesuai dengan peran atau tugasnya dalam periode tertentu, yang dihubungkan dengan ukuran nilai atau standar tertentu dari organisasi tempat individu tersebut bekerja

Menurut Rivai dalam Rachmawati (2017) pelatihan merupakan upaya untuk meningkatkan kualitas sumber daya manusia. Pelatihan membantu pegawai dalam memahami suatu pengetahuan praktis dan penerapannya, guna meningkatkan keterampilan, kecakapan, dan sikap yang diperlukan oleh perusahaan dalam usaha mencapai tujuan. Pelatihan memiliki orientasi saat ini dan membantu pegawai untuk mencapai keahlian dan kemampuan tertentu agar berhasil dalam melaksanakan pekerjaannya. Rattu, Kindangen, \& Taroreh (2018) menjelaskan bahwa pelatihan merupakan wadah lingkungan bagi karyawan, dimana mereka mendapatkan pelajaran dalam hal-hal yang berkaitan dengan tugas dan tanggung jawab seperti perilaku, pengetahuan, kemampuan dan keahlian serta sikap. Pelatihan kerja merupakan proses pembelajaran yang melibatkan perolehan keahlian, konsep, peraturan, atau sikap untuk meningkatkan kinerja karyawan. Menurut Widodo \& Muhibin (2018) pelatihan dimaksudkan untuk memperbaiki penguasaan berbagai keterampilan dan teknik pelaksanaan kerja tertentu. Pada setiap aktivitas pasti memiliki arah yang dituju, baik jangka pendek maupun jangka panjang. Arah yang dituju merupakan rencana yang dinyatakan sebagai hasil yang dicapai. Manfaat dan dampak yang diharapkan dari pelatihan harus dirumuskan dengan jelas dan tidak mengabaikan kemampuan perusahaan.

Handoko dalam Leatemia (2018) menyatakan bahwa pengalaman kerja merupakan penguasaan pengetahuan dan keterampilan karyawan yang diukur dari lama masa kerja, tingkat pengetahuan dan keterampilan yang dimiliki karyawan. Menurut Marwansyah dalam Kaengke, Tewal, \& Uhing (2018) pengalaman kerja adalah suatu pengetahuan, keterampilan, dan kemampuan yang dimiliki pegawai untuk mengemban tanggung jawab dari pekerjaan yang sebelumnya dilakukan. Pengalaman kerja merupakan pedoman seseorang dalam memilih profesi yang tepat bagi dirinya. Orang yang pernah memiliki pengalaman kerja akan lebih selektif dalam memilih profesi yang cocok untuk dirinya. Menurut Sutrisno dalam Octavianus (2018) pengalaman kerja adalah suatu dasar / acuan seorang karyawan dapat menempatkan diri secara tepat kondisi, berani mengambil resiko, mampu menghadapi tantangan dengan penuh tanggung jawab serta mampu berkomunikasi dengan baik terhadap berbagai pihak untuk tetap menjaga produktivitas, kinerja dan menghasilkan individu yang kompeten dalam bidangnya. Sedangkan menutut Hariandja dalam Mamangkey, Tumbel, \& Uhing (2015) menyatakan 
pengalaman kerja adalah suatu pekerjaan atau jabatan yang pernah diduduki sebelumya selama kurun waktu tertentu.

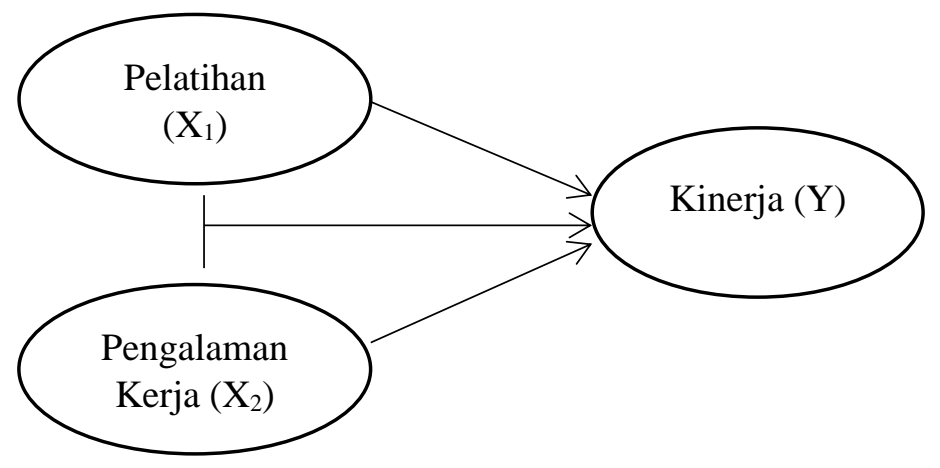

Gambar 1. Kerangka pemikiran

\section{METODE PENELITIAN}

Penelitian ini bertujuan untuk menganalisis pengaruh pelatihan dan pengalaman kerja terhadap kinerja karyawan PT. Yi Shen Industrial. Metode yang digunakan yaitu regresi linear berganda dan sederhana. Beberapa metode analisis data yang digunakan adalah kuesioner, sehingga diperlukan pemaparan hasil tanggapan responden terkait kuesioner.

Teknik sampling yang digunakan adalah teknik sampling jenuh, yaitu uji analisis instrumen penelitian guna teknik pengambilan sampel bila semua anggota digunakan sebagai sampel. Istilah lain sampel jenuh adalah sensus, dimana semua anggota populasi dijadikan sampel. Sampel sudah maksimum, ditambah beberapa tidak akan merubah keterwakilan, (Bintarti, 2015).

Berdasarkan penelitian karena jumlah populasinya tidak lebih besar dari 100 responden, maka jumlah populasi yang diambil seluruh karyawan lapangan yang ada pada PT. Yi Shen Industrial. Semua populasi dijadikan sampel tanpa memperhatikan strata yang ada dalam populasi ini. Jumlah sampel dalam penelitian ini adalah 76 responden. Kuesioner penelitian terdiri dari kuesioner yang disebar dalam bentuk fisik.

Kuesioner terdiri dari tiga bagian. Bagian pertama adalah pertanyaan penyaring. Bagian kedua adalah pertanyaan inti terkait variabel penelitian dalam bentuk skala likert 1 sampai 5 yang terdiri dari 3 variabel dan total 30 pertanyaan. Pertanyaan skala likert membagi pilihan dari sangat tidak setuju, tidak setuju, agak tidak setuju, setuju dan sangat setuju. Bagian ketiga terdiri dari data demografi responden. Pertanyaan demografi mengetahui gambaran umur responden terkait jenis kelamin, umur, dan pendidikan terakhir responden.

Analisis reliabilitas mengukur konsistensi item pertanyaan penelitian dalam bentuk skala 
dan stabilitas pengukuran dari setiap dimensi. Hasil uji reliabilitas menunjukan angka diatas 0,6 pada setiap variabel penelitian sehingga dapat dipastikan pertanyaan penelitian reliabel. Analisis validitas bertujuan menguji apakah pertanyaan penelitian memberikan hasil yang tepat sesuai tujuan. Berdasarkan uji validitas menunjukan angka KMO diatas 0,7 dan tes bartlett dibawah 0,000 dan dapat dipastikan pertanyaan penelitian valid untuk diuji.

\section{HASIL DAN PEMBAHASAN}

Hasil uji validitas dan reliabilitas dari kuisioner yang telah dibagikan menghasilkan sebagaimana tercantum pada tabel 2. Dari uji coba yang telah dilakukan dapat diketahui bahwa hasil Cronbach's Alpha setiap variabel lebih dari standar minimal yang ditentukan yaitu 0,6 maka variabel pelatihan, pengalaman kerja dan kinerja dapat dikatakan reliabel.

Tabel 2. Hasil Uji Reliabilitas

\begin{tabular}{|l|c|c|}
\hline \multicolumn{1}{|c|}{ Variabel } & N Item & Nilai Cronbach Alpha \\
\hline Pelatihan & 9 & 0,769 \\
\hline Pengalaman Kerja & 9 & 0,730 \\
\hline Kinerja & 12 & 0,605 \\
\hline
\end{tabular}

Sumber: Hasil analisis data (2019)

Hasil penelitian menunjukkan bahwa nilai Kaiser Meyer Olkin Measure of Sampling (KMO) untuk variabel pelatihan, pengalaman kerja dan kinerja lebih dari 0,5. Dengan demikian nilai KMO telah memenuhi persyaratan karena memiliki nilai diatas 0,5 . Hasil perhitungan bartlett test of sphericity 129,624 dengan signifikansi sebesar 0,000. Dengan demikian bartlett test of sphericity telah memenuhi persyaratan karena signifikansi di bawah 0,05 (5\%).

Tabel 3. Hasil Uji Validitas

\begin{tabular}{|c|c|c|}
\hline Variabel & Test $\mathbf{K M O}$ & Bartlett Tes \\
\hline Pelatihan & 0,574 & 0,000 \\
\hline Pengalaman Kerja & 0,492 & 0,000 \\
\hline Kinerja & 0,541 & 0,000 \\
\hline
\end{tabular}

Sumber: Hasil analisis data (2019)

Analisis regresi linier berganda dilakukan untuk mengetahui dan menguji seberapa besar pengaruh antara pelatihan kerja, pengalaman kerja dan kinerja karyawan. Hal ini disajikan dalam Tabel 4. 
Tabel 4. Koefisien Pengaruh Pelatihan dan pengalaman kerja terhadap kinerja

Coefficients $^{\mathrm{a}}$

\begin{tabular}{|c|c|c|c|c|c|c|}
\hline \multirow{2}{*}{\multicolumn{2}{|c|}{ Model }} & \multicolumn{2}{|c|}{$\begin{array}{c}\text { Unstandardized } \\
\text { Coefficients }\end{array}$} & \multirow{2}{*}{\begin{tabular}{|c|}
$\begin{array}{c}\text { Standardized } \\
\text { Coefficients }\end{array}$ \\
Beta \\
\end{tabular}} & \multirow[b]{2}{*}{$t$} & \multirow[b]{2}{*}{ Sig. } \\
\hline & & B & Std. Error & & & \\
\hline & (Constant) & 1,273 & 2,113 & & ,603 &, 549 \\
\hline & Pelatihan & 1,108 & ,043 & ,901 & 25,913 & ,000 \\
\hline & $\begin{array}{l}\text { Pengalaman } \\
\text { kerja }\end{array}$ & ,201 & ,055 &, 126 & 3,622 & ,001 \\
\hline
\end{tabular}

a. Dependent Variable: Kinerja

Sumber: Hasil analisis data (2019)

Tabel 5. Hasil Analisis Parsial

\begin{tabular}{|c|c|c|c|}
\hline Variabel & $\boldsymbol{T}_{\text {hitung }}$ & $\boldsymbol{T}_{\text {tabel }}$ & Keterangan \\
\hline $\mathrm{X}_{1}$ & 25,913 & 1,993 & Ada pengaruh signifikan \\
\hline $\mathrm{X}_{2}$ & 3,622 & 1,993 & Ada pengaruh signifikan \\
\hline
\end{tabular}

Sumber: Hasil analisis data, 2019

Berdasarkan hasil uji t pada tabel 4 dan tabel 5 di atas, dapat diperoleh hasil sebagai berikut:

1. Pengujian hipotesis variabel pelatihan kerja

Hasil pengujian menunjukkan bahwa nilai signifikansi variabel pelatihan sebesar 0,000<0,05. Diperoleh $t_{\text {hitung }}$ sebesar 25,913 dan $t_{\text {tabel }}$ sebesar 1,993 dimana Degree of Freedom (df) $n-k-1$ atau 76-2-1 = 73 dengan pengujian 2 sisi (signifikansi $=0,025)$. Karena $t_{\text {hitung }}>t_{\text {tabel }}$ (25.913>1.993) maka Ho ditolak. Hal ini artinya bahwa pelatihan berpengaruh terhadap kinerja karyawan. Nilai thitung positif, artinya berpengaruh positif yakni semakin meningkat pelatihan maka semakin meningkat pula kinerja karyawan. Dari hasil tersebut dapat disimpulkan bahwa, pelatihan secara parsial berpengaruh positif dan signifikan terhadap kinerja.

2. Pengujian hipotesis variabel pengalaman kerja

Hasil pengujian menunjukkan bahwa nilai signifikansi variabel pengalaman kerja sebesar 0,001<0,05. Diperoleh $t_{\text {hitung }}$ sebesar 3,622 dan $t_{\text {tabel }}$ sebesar 1,993 dimana Degree of Freedom (df) $n-k-1$ atau 76-2-1 = 73 dengan pengujian 2 sisi (signifikansi $=0,025$ ). Karena $t_{\text {hitung }}>t_{\text {tabel }}$ $(3,622>1,993)$ maka Ho ditolak, artinya bahwa pengalaman kerja berpengaruh terhadap kinerja karyawan. Nilai thitung positif, artinya berpengaruh positif yakni semakin meningkat pengalaman kerja maka semakin meningkat pula kinerja karyawan. Dari hasil tersebut dapat disimpulkan bahwa, variabel pengalaman kerja secara parsial berpengaruh positif dan signifikan terhadap kinerja karyawan. 
Tabel 6. Anova (Dengan signifikansi a $=5 \%$ )

\begin{tabular}{|c|c|c|c|c|c|c|}
\hline \multicolumn{7}{|c|}{ ANOVA $^{a}$} \\
\hline & Model & $\begin{array}{l}\text { Sum of } \\
\text { Squares }\end{array}$ & $D f$ & $\begin{array}{c}\text { Mean } \\
\text { Square }\end{array}$ & $\boldsymbol{F}$ & Sig. \\
\hline \multirow[t]{3}{*}{1} & Regression & 968,765 & 2 & 484,382 & 484,220 &, $000^{\mathrm{b}}$ \\
\hline & Residual & 73,025 & 73 & 1,000 & & \\
\hline & Total & 1041,789 & 75 & & & \\
\hline
\end{tabular}

a. Dependent Variable: Kinerja

b. Predictors: (Constant), Pelatihan, Pengalaman kerja

Sumber: Hasil analisis data (2019)

Tabel 7. Hasil Uji F

\begin{tabular}{|c|c|c|}
\hline $\boldsymbol{F}_{\text {Hitung }}$ & $\boldsymbol{F}_{\text {Tabel }}$ & Keterangan \\
\hline 484,220 & 3,12 & Ada Pengaruh Signifikan \\
\hline
\end{tabular}

Sumber: Hasil analisis data (2019)

Berdasarkan hasil perhitungan menggunakan SPSS versi 22, dapat dilihat bahwa $\mathrm{f}_{\text {hitung }}>$ $\mathrm{f}_{\text {tabel }}(484,382>3,12)$ dengan nilai signifikansi $0,000<0,05$. Maka sesuai dengan dasar pengambilan keputusan dalam uji $\mathrm{F}$ yang telah ditentukan oleh peneliti dapat disimpulkan bahwa variabel pelatihan $\left(\mathrm{X}_{1}\right)$ dan variabel pengalaman kerja $\left(\mathrm{X}_{2}\right)$ secara signifikan dan simultan bersama sama berpengaruh terhadap variabel kinerja (Y).

Tabel 8. Koefisien Determinasi

\begin{tabular}{|l|l|r|r|c|}
\hline Model & $\boldsymbol{R}$ & $\boldsymbol{R}$ Square & $\begin{array}{c}\text { Adjusted } \boldsymbol{R} \\
\text { Square }\end{array}$ & $\begin{array}{c}\text { Std. Error of the } \\
\text { Estimate }\end{array}$ \\
\hline 1 &, $964^{\mathrm{a}}$ &, 930 &, 928 & 1,000 \\
\hline
\end{tabular}

a. Predictors: (Constant), Pelatihan, Pengalaman kerja

b. Dependent Variable: Kinerja

Sumber: Hasil analisis data (2019)

Berdasarkan Tabel 8 di atas output diperoleh angka Adjusted $R$ Square sebesar 0,928 atau $(92,8 \%)$. Hal ini menunjukkan bahwa persentase kontribusi pengaruh variabel independen pelatihan dan pengalaman kerja terhadap variabel dependen kinerja sebesar 92,8\%, sedangkan $7,2 \%$ dipengaruhi oleh variabel lain yang tidak dimasukkan dalam penelitian ini.

\section{Pengaruh Variabel Pelatihan Terhadap Kinerja Karyawan PT. Yi Shen Industrial}

Hasil pengujian reliabilitas menunjukkan bahwa nilai Cronbach's alpha di atas 0,60 sehingga dapat dikatakan reliabel. Hal tersebut dapat dilihat dari hasil pengujian yang telah dilakukan melalui SPSS, dimana pelatihan $\left(\mathrm{X}_{1}\right)$ nilai Cronbach's alpha sebesar 0,605. Hasil dari persamaan regresi linier sederhana diperoleh persamaan $Y=1,273+1,108 X_{1}+0,201 X_{2}$. Hal ini menunjukkan bahwa semakin tinggi pelatihan kerja maka semakin meningkatkan 
kinerja karyawan. Dari hasil analisis menunjukkan bahwa uji t untuk variabel pelatihan diperoleh $t_{\text {hitung }}$ sebesar 25,913 dan $t_{\text {tabel }}$ sebesar 1,993 yang berarti $t_{\text {hitung }}>t_{\text {tabel }}$ maka, Ho ditolak Ha diterima dengan tingkat signifikan sebesar $0,000<0,05$. Hasil dari perhitungan tersebut menunjukkan bahwa variabel pelatihan secara parsial terdapat pengaruh positif dan signifikan terhadap variabel kinerja.

\section{Pengaruh Variabel Pengalaman Kerja Terhadap Kinerja Karyawan PT. Yi Shen Industrial}

Hasil pengujian reliabilitas menunjukkan bahwa nilai Cronbach's alpha di atas 0,60 sehingga dapat dikatakan reliabel. Hal tersebut dapat dilihat dari hasil pengujian yang telah dilakukan melalui SPSS dimana pengalaman kerja $\left(\mathrm{X}_{2}\right)$ nilai Cronbach's alpha sebesar 0,730. Hasil dari persamaan regresi linier sederhana diperoleh persamaan $Y=1,273+1,108 X_{1}+0,201$ $\mathrm{X}_{2}$. Hal ini menunjukkan bahwa semakin tinggi pengalaman kerja maka semakin meningkatkan kinerja.

Dari hasil analisis menunjukkan bahwa uji t untuk variabel pengembangan karier diperoleh $t_{\text {hitung }}$ sebesar 3,622 dan $t_{\text {tabel }}$ sebesar 1,993. Hal ini berarti $t_{\text {hitung }}>t_{\text {tabel }}$ maka, Ho ditolak Ha diterima dengan tingkat signifikan sebesar $0,001<0,05$. Hasil dari perhitungan tersebut menunjukkan bahwa variabel pengalaman kerja secara parsial terdapat pengaruh positif dan signifikan terhadap variabel kinerja.

\section{Pengaruh Variabel Pelatihan dan Pengalaman Kerja Terhadap Kinerja Karyawan PT.}

\section{Yi Shen Industrial}

Berdasarkan hasil yang dilakukan melalui Uji F diperoleh nilai F hitung sebesar 484,220 sedangkan $F$ tabel sebesar 3,12 sehingga $F_{\text {hitung }}>F_{\text {tabel }}$, maka Ho ditolak Ha diterima dengan tingkat signifikan sebesar $0,000<0,05$. Hal ini berarti bahwa pelatihan dan pengalaman kerja secara bersama-sama berpengaruh positif dan signifikan terhadap kinerja karyawan.

\section{E. KESIMPULAN}

Berdasarkan analisis dan pembahasan di atas serta tujuan dari penelitian ini yaitu untuk mengetahui pengaruh pelatihan dan pengalaman kerja teradap kinerja karyawan, maka dapat ditarik kesimpulan sebagai berikut :

1. Terdapat pengaruh pelatihan terhadap kinerja kinerja karyawan pada PT. Yi Shen Industrial. Dilihat dari hasil pengolahan data SPSS yang mana diperoleh $t_{\text {hitung }}>\mathrm{t}_{\text {tabel }}$ $(25,913>1,993)$ maka, Ho ditolak Ha diterima, dengan tingkat signifikan 0,000<0,05. Hal ini artinya pelatihan memiliki pengaruh terhadap kinerja karyawan pada PT. Yi Shen 
Industrial. Nilai thitung positif, artinya berpengaruh positif yakni semakin meningkat pelatihan maka semakin meningkat pula kinerja karyawan. Dari hasil tersebut dapat disimpulkan bahwa variabel pelatihan secara parsial berpengaruh positif dan signifikan terhadap kinerja karyawan pada PT. Yi Shen Industrial.

2. Terdapat pengaruh pengalaman kerja terhadap kinerja karyawan pada PT. Yi Shen Industrial. Dilihat dari hasil pengolahan data SPSS yang mana diperoleh $t_{\text {hitung }}>t_{\text {tabel }}$ $(3,622>1,993)$ maka, Ho ditolak Ha diterima, dengan tingkat signifikan 0,000<0,05. Hal ini artinya pengalaman kerja memiliki pengaruh terhadap kinerja karyawan pada PT. Yi Shen Industrial. Nilai $t_{\text {hitung }}$ positif, artinya berpengaruh positif yakni semakin meningkat pengalaman kerja maka semakin meningkat pula kinerja karyawan. Dari hasil tersebut dapat disimpulkan bahwa variabel pengalaman kerja secara parsial berpengaruh positif dan signifikan terhadap kinerja karyawan PT. Yi Shen Industrial

3. Terdapat pengaruh simultan antara pelatihan dan pengalaman kerja terhadap kinerja karyawan. Dilihat dari hasil pengolahan data SPSS yang mana diperoleh $f_{\text {hitung }}>f_{\text {tabel }}$ (484,220>3,12), maka Ho ditolak Ha diterima dengan tingkat signifikan sebesar $0,000<0,05$. Dapat disimpulkan bahwa dari kedua variabel pelatihan dan variabel pengalaman kerja secara bersama-sama memiliki pengaruh positif dan signifikan terhadap variabel kinerja karyawan.

\section{DAFTAR PUSTAKA}

Al Karim, R. (2019). Impact of different training and development programs on employee performance in Bangladesh perspective. International Journal of Entrepreneurial Research, 2(1), 8-14.

Anggita, A., \& Tjahyanti, S. (2017). Pengaruh Pelatihan, Pengalaman Kerja Dan Lingkungan Kerja Terhadap Kinerjapegawai Negeri Sipil. Jurnal Bisnis dan Akuntansi, 19(2), 7681.

Bintarti, S. (2015). Metodologi penelitian ekonomi manajemen. Jakarta: Mitra Wacana Media.

Kaengke, A. S., Tewal, B., \& Uhing, Y. (2018). Pengaruh Pengembangan Karir, Pelatihan Dan Motivasi Terhadap Kinerja Karyawan Pada PT Air Manado. Jurnal EMBA: Jurnal Riset Ekonomi, Manajemen, Bisnis dan Akuntansi, 6(1).

Kapahang, J. O., Kojo, C., \& Uhing, Y. (2017). Pendidikan, Pengalaman Kerja Dan Kompetensi Pengaruhnya Terhadap Kinerja Karyawan Pada PT. PLN (Persero) Wilayah Suluttenggo. Jurnal EMBA: Jurnal Riset Ekonomi, Manajemen, Bisnis dan Akuntansi, 2(4). 
Leatemia, S. Y. (2018). Pengaruh Pelatihan Dan Pengalaman Kerja Terhadap Kinerja Pegawai (Studi pada Kantor Badan Pusat Statistik di Maluku). Manajemen dan Bisnis, 2(1).

Mamangkey, T. J., Tumbel, A., \& Uhing, Y. (2015). Pengaruh pelatihan, pengalaman dan lingkungan kerja terhadap kinerja karyawan pada PT. Bangun Wenang Beverages Company Manado. Jurnal EMBA: Jurnal Riset Ekonomi, Manajemen, Bisnis dan Akuntansi, 3(1).

Octavianus, W. R. (2018). Pengaruh Pengalaman Kerja Dan Pelatihan Kerja Terhadap Kinerja Karyawan PT. Telkom Indonesia Cabang Manado. Jurnal EMBA. Jurnal Riset Ekonomi, Manajemen, Bisnis dan Akuntansi, 6(3).

Rachmawati, R. W. (2017). Pengaruh Pelatihan dan Motivasi Kerja terhadap Kinerja Karyawan PT. Bank Bjb Kantor Cabang Suci Bandung. Jurnal Manajemen dan Pemasaran Jasa, 9(1), 1-16.

Rattu, C. N., Kindangen, P., \& Taroreh, R. N. (2018). Pengaruh Pendidikan, Pelatihan Dan Kompensasi Terhadap Kinerja Karyawan Pada PT. Air Manado. Jurnal EMBA: Jurnal Riset Ekonomi, Manajemen, Bisnis dan Akuntansi, 6(3).

Widodo, W., \& Muhibin, S. M. (2018). Pengaruh Pendidikan Dan Pelatihan Serta Motivasi Kerja Terhadap Kinerja Karyawan PT. Asuransi Jasa Indonesia (Persero). Jurnal Manajemen Bisnis Krisnadwipayana, 6(2).

Yunita, R. I., \& Zuhro, D. (Januari 2018). Performa Kepemimpinan Terhadap Kinerja Karyawan. JPM17: Jurnal Pengabdian Masyarakat, 3(1), 7-21 